\title{
A statistical analysis of corpus based approach on learning sentence patterns
}

\author{
S. Bhargavi, K. Anbazhagan \\ Department of English and Foreign Languages, SRM Institue of Science and Technology, India
}

\begin{tabular}{|c|c|}
\hline Article Info & ABSTRACT \\
\hline Article history: & This research paper examines the adverse effect of theoretical explanation \\
\hline Received Nov 26, 2018 & $\begin{array}{l}\text { of the grammatical rules among the learners. Exploration of the methods } \\
\text { and materials taught inductively or deductively is the panacea to achieve }\end{array}$ \\
\hline Revised May 8, 2020 & the required goal. The study throws light on the pedagogical implication of \\
\hline Accepted May 21, 2020 & $\begin{array}{l}\text { adopting appropriate methods and materials for building the learners' grammar } \\
\text { and language. It primarily intends to explore a new teaching method using }\end{array}$ \\
\hline Keywords: & $\begin{array}{l}\text { language corpora that can be employed in the English grammar classes in } \\
\text { colleges at the undergraduate level. It strives to evaluate the effectiveness of }\end{array}$ \\
\hline $\begin{array}{l}\text { Corpus based teaching } \\
\text { Sentence patterns }\end{array}$ & $\begin{array}{l}\text { teaching sentence patterns through corpus-based activities comparing with } \\
\text { the traditional based teaching. Thus, the methodology aims to encourage } \\
\text { students to become independent corpus users. }\end{array}$ \\
\hline
\end{tabular}

Copyright $(0) 2020$ Institute of Advanced Engineering and Science. All rights reserved.

\section{Corresponding Author:}

S. Bhargavi,

Department of English and Foreign Languages,

SRM Institue of Science and Technology,

Kattankulathur, Chennai, Tamilnadu, India.

Email: bhargavi.s@ktr.srmuniv.ac.in

\section{INTRODUCTION}

"What I know about grammar is its infinite power." - Joan Didion. The pivotal contributions of computer sciences in changing the perspective towards language teaching and learning have been observed within corpus linguistics. The approaches through tools and evidences related to corpus have been assisting linguistic research [1]. This can be understood through Lee's point about the efficiency of a number of corpora like BNC, COCA which have been acknowledged as important teaching tools of English language [2]. Many Corpus linguists and language professionals acknowledge the advantages of corpora and highly recommend the integration of corpus based activities into language teaching and learning.

Research problem and research questions: A keen examination through numerous studies on grammar and usage unveils the fact that a strong emphasis should be laid not only on structural analysis but also in the description of grammatical functions [3]. Many students often are likely to be incompetent in English grammar classes. Even students who have command over the necessary language skills may be unfamiliar with the proper grammatical constructions [4]. Lack of time and confidence, lack of appropriate teaching and learning materials, lack of innovative speaking and writing activities in academic contexts can be considered as few barriers in acquiring English language [5]. In comparison with the traditional based activities of teaching and learning, the research aims at evaluating the effectiveness of corpus-based activities. Therefore, the following questions directed the current paper.

- What are the adverse effects of theoretical explanation of the grammatical rules at the undergraduate level?

- Is corpus useful for learning grammatical rules?

- How corpus-based activities can be integrated into teaching sentence patterns?

- Does exist a significant difference exist between the scores of the pretest and posttest of the control and the experimental group? 
Lack of detailed descriptions and applications: Grammar teaching and learning in English classes is often non-constructive for many students who show less inclination towards its acquisition [6]. Vavra cautioned against the ways of teaching grammar by pointing its ineffectiveness due to the fact that instruction is targeted on individual rules, exceptions and individual simplistic sentences and in practice, if no longer in theory, grammar regularly fills the cart lacking the connection with the horse [7]. Paralleling the improvisations in the constituents of the grammatical courses taught at the university over the years, considerable activities are being conducted [8]. Still, some areas of grammar seem to be difficult at the UG level which affects the application of grammatical rules in their own writing.

The necessity of adopting appropriate approaches: Corpus based analysis of the students has based on a structure of method designed and implemented from approaches such as corpus linguistics into second language acquisition [9]. The vast consideration of the discredit of the explicit teaching of prescriptive language forms however that nothing had been put in its location [10]. The uncertainty of the learners was reasonably enormous in not enrolling in the weekly duration of physical activities and the uneasiness was due to the lack of standard attention to language, hence this necessitated the readiness of the teachers to broaden new strategies to language teaching [11]. In English classes, teachers often try to resolve many uncertainties that encircle grammar teaching. Finding an ideal solution to solve the linguistic obstacles is the need of the hour [12].

Exploiting corpus for learning activities: Wu pointed out that irrespective of the intuition of native speakers, English teachers of non-native speaker could make responses based on principled corpora to resolve grammatical and utilization issues [13]. Studies so far have proven that grammar instruction through corpus is largely advantageous in linguistics descriptive [14]. It helps the learners in procuring and exploring the linguistic resources in English. Figure 1 represents the possible outcomes of teaching grammar through corpus.

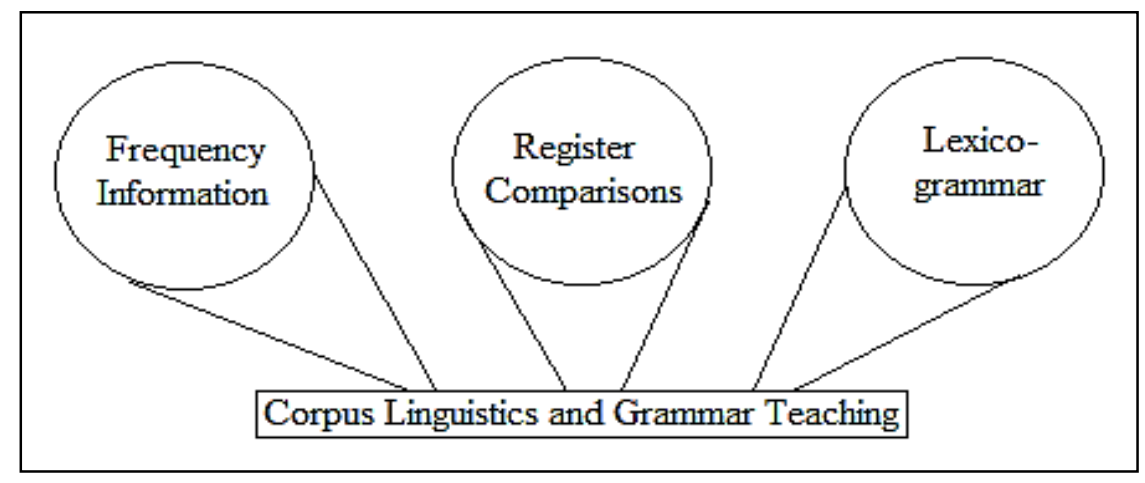

Figure 1. The salient outcomes of corpus-based grammar teaching [15]

The centre of interest of this approach is on structure and meaning. With no emphasis on the language form and structure, the learners begin an activity [16]. After the completion of the activity, follows a presentation. At this juncture, learners get a meaningful input devoid of formal grammatical instruction [17]. English language instructors strongly believe that learners will be propelled to acquire the language forms easily. Sufficient guidance from the instructors while reaching the conclusions and rules helps to reach a sense of achievement in learning [18].

Romer [19] surveyed 78 EFL teachers to identify their varied basic needs such as effective materials for teaching books showing real language, methods of easy and quick creation and access of materials, possible ways for gradation, the unreliability of the native speakers. The resources through corpus-based methodology such as text books, DDL materials, proper training for teachers in the self creation of materials, assistants to the native speakers [20]. Also, Romer recommended the association of teachers in identifying and delivering their needs. Camiciottoli investigated the effect of the Suse of future progressive tense for 14 times among which 9 had the combination of the verb 'talk' by the lecturers of native language [21]. The reason behind was observed to be the continuity of the lectures extracted from the corpus named MICASE [22]. The lectures lead to an experience with progressive learning during sequential class meetings. This was observed to vary with the isolated guest lectures. Salom et al., [23] analyzed 50 research articles and 15 technical reports and showed the necessity of evaluative language as a lexico grammatical tool for understanding interpersonal meanings with the persuasion of the readers through the writer's view and research validity. The proposal of a tool for lexico-grammatical assessment could be beneficial for academic 
reading and writing skill [24]. Stotesbury 2003 investigated discussion sections included in the engineering texts focusing on the resources of appraisal that indicate evaluation, attitude, modality and certainty. The researchers utilized a corpus of 46 researches in the fields of telecommunications, computer science, nanotechnology and robotics [25]. The educational groups could be persuaded about the validity of the study provided and the handiness of accepting new information-claims according to the writers' point of view in the discussion sections in the academic papers [26]. Latest studies on lexico-grammatical ways of implementing attitudes, interpretations and evaluation of truth value on readers has been performed in particular disciplines [27].

\section{RESEARCH METHOD}

\subsection{Participants}

The study undertaken involved 36students of a university whose age ranged from 17 to 19 majoring in the area of Mathematics. Two classes were sampled and were considered as the control group ( $\mathrm{n}=18)$ and the experimental group $(n=18)$. The availability of language laboratory for experimenting the activities assisted in the creation of groups on the basis of convenient sampling from the first year students of the batch 2016-17. Arbitrary selection of students into groups was made with the quasi- experimental research design. The BYU-BNC created by Oxford University Press was used to create various activities.

\subsection{Instrumentation}

The instruments of the study comprised i) a pretest with exercises of 40 questions on gap filling, multiple choice and matching the correct answers etc., the participants were considered to be in the lower and the intermediate levels based on the acquisition of the scores. This was done to determine their proficiency in grammar and ii) an achievement test was developed by the researchers with 40 questions under various subparts and the reliability of this posttest was evaluated through a panel of experts in the related field.

\subsection{Procedure}

At the beginning of the study the pretest i.e., the language proficiency test was administered to both the control and the experimental groups. The syllabus covered 'sentence patterns' which necessitated the usage of many reference books. The researchers used the deductive method of teaching sentence patterns that had involved the process of instruction before application in the control group. This traditional way of teaching provided the students an explanation of the concept in depth before they had practiced them in their own writing. The students were found to be in a state of boredom of rote learning as they felt it to be the teacher-centered approach. But the students in the experimental group were taught based on the collocations of a particular key word. The treatment lasted for 8 weeks with 3 sessions per week. The researchers taught the experimental group to access the BYU-BNC corpus. The researchers used the inductive method of teaching with various illustrations on a particular sentence pattern and the students were allowed to observe how the pattern worked from the given examples. Explanation of the concept was not given in prior to promote the natural way of recognizing the grammatical rules. Repetition and renewal of activities with various worksheets were carried out to help the students discover grammar and examine how the rules were employed in a sentence. This method aimed to retain the concept by helping the students to work cognitively. At the end of the treatment, both the groups undertook the achievement test.

\section{RESULTS AND DISCUSSION}

To compare the effect of corpus based grammar teaching on achievement test scores the statistical analysis software called Minitab was used. The instruments and procedures mentioned above helped in collecting the required data. The researchers examined the research questions by analyzing the data. The t-test assisted in the comparison of the level of language proficiency of the participants in the pretest and the posttest.

The results of Table 1 indicates that there is no statistically significant difference where $\mathrm{t}(28)=-2.13, \mathrm{p}=0.052$ between the two-sampled pretest of the control group with $\mathrm{M}=17.83, \mathrm{SD}=3.47$ and experimental group with $\mathrm{M}=19.89, \mathrm{SD}=2.19$. This shows the similarity in the knowledge of the participants in sentence patterns at the commencement of the study. The results of Table 2 indicates that the out performance of the experimental group where $\mathrm{t}(28)=-6.13, \mathrm{p}=0.01$ between the two-sampled posttest of the control group with $\mathrm{M}=24.67, \mathrm{SD}=4.12$ and experimental group with $\mathrm{M}=33.06, \mathrm{SD}=4.09$. This shows the existence of a significant level of knowledge of sentence patterns of the students in the experimental group than the students in the control group. The comparison suggests that sentence patterns taught through corpus based activities were highly effective (as APPENDIX). 
Table 1. Results for test of structure (pretest)

\begin{tabular}{|c|c|c|c|c|c|c|c|c|c|}
\hline \multirow[b]{2}{*}{ Sample } & \multicolumn{4}{|c|}{ Descriptive Statistics } & \multicolumn{2}{|c|}{ Estimation of Difference } & \multicolumn{3}{|c|}{ Test } \\
\hline & $\mathrm{N}$ & Mean & $\mathrm{tDev}$ & SE & $\begin{array}{c}\text { Mean } \\
\text { Difference }\end{array}$ & $\begin{array}{l}95 \% \text { CI for } \\
\text { Difference }\end{array}$ & T-Value & DF & P-Value \\
\hline $\begin{array}{l}\text { CG } \\
\text { EG }\end{array}$ & $\begin{array}{l}18 \\
18\end{array}$ & $\begin{array}{l}17.83 \\
19.89\end{array}$ & $\begin{array}{l}3.47 \\
2.19\end{array}$ & $\begin{array}{l}0.82 \\
0.52\end{array}$ & -2.056 & $(-4.037,-0.074)$ & -2.13 & 28 & 0.052 \\
\hline
\end{tabular}

Table 2. Results for test of structure (posttest)

\begin{tabular}{|c|c|c|c|c|c|c|c|c|c|}
\hline \multirow[b]{2}{*}{ Sample } & \multicolumn{4}{|c|}{ Descriptive Statistics } & \multicolumn{2}{|c|}{ Estimation ofDifference } & \multicolumn{3}{|c|}{ Test } \\
\hline & $\mathrm{N}$ & Mean & $\mathrm{tDev}$ & SE & $\begin{array}{c}\text { Mean } \\
\text { Difference }\end{array}$ & $\begin{array}{l}\text { 95\% CI for } \\
\text { Difference }\end{array}$ & T-Value & $\mathrm{DF}$ & P-Value \\
\hline $\mathrm{CG}$ & 18 & 24.67 & 4.12 & 0.97 & -8.39 & $(-11.17,-5.60)$ & -6.13 & 28 & 0.01 \\
\hline
\end{tabular}

\section{CONCLUSION}

The results of the study of the language learning program indicated the outperformance of the participants in the experimental group that involved the corpus-based achievement of learning a grammatical component namely sentence pattern. This investigation helped in finding more opportunities for the grammar learning. The research paper shows how corpus linguistics and English grammar teaching can be integrated. It can be said that the benefits of using corpus based activities should not be ignored in language classes. Unfortunately, in most classrooms, less preference is given for its usage [28]. But it is an undeniable fact that a learner, who makes good use of a corpus will be able to expand educational horizons, gives him considerable autonomy over his own learning. Therefore, Corpus based teaching and learning should be an integral part of any syllabus.

\section{APPENDIX}

Corpus-based exercise create and analyze the concordance lines and complete the table given:

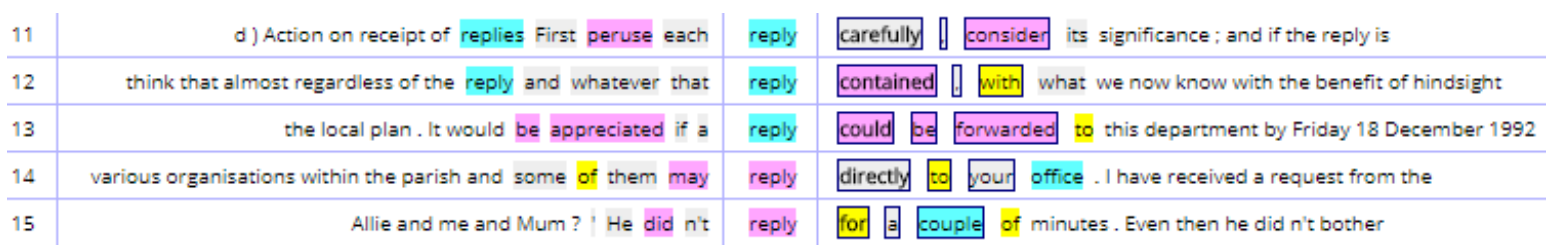

$\mathrm{S}=$ Subject, $\mathrm{V}=$ Verb, $\mathrm{O}=$ Object, $\mathrm{IO}=$ Indirect Object, $\mathrm{DO}=$ Direct Object, $\mathrm{A}=$ Adjunct, $\mathrm{C}=$ Complement

\begin{tabular}{cc}
\hline Sentence Patterns & Sentences from concordance lines \\
$\mathrm{S}+\mathrm{V}$ & \\
$\mathrm{S}+\mathrm{V}+\mathrm{C}$ & \\
$\mathrm{S}+\mathrm{V}+\mathrm{IO}+\mathrm{DO}$ & \\
$\mathrm{S}+\mathrm{V}+\mathrm{O}+\mathrm{A}$ & \\
$\mathrm{S}+\mathrm{V}+\mathrm{O}+\mathrm{C}+\mathrm{A}$ & \\
\hline
\end{tabular}

\section{REFERENCES}

[1] M. Stubbs, "Text and corpus analysis: Computer-assisted studies of language and culture," Wiley-Blackwell, 1996.

[2] S. Lee, "Challenges of Using Corpora in Language Teaching and Learning: Implications for Secondary Education," Linguistic Research, vol. 28, no. 1, pp. 159-178, 2011.

[3] J. R. Taylor and J. R. Taylor, "Possessives in English: An exploration in cognitive grammar," Clarendon Press Oxford, 1996.

[4] J. M. O'malley, et al., "Learning strategy applications with students of English as a second language," TESOL quarterly, vol. 19, no. 3, pp. 557-584, 1985.

[5] K. W. Lee, "English teachers' barriers to the use of computer-assisted language learning," The internet TESL Journal, vol. 6, no. 12, pp. 1-8, 2000.

[6] M. Tamim, "Consistencies and Inconsistencies BetweenTeachers' Beliefs and Practices," The Qualitative Report, vol. 20, no. 8, pp. 1234-1259, 2015.

[7] E. Vavra, "On Not Teaching Grammar," English Journal, vol. 85, no. 7, pp. 32-37, 1996.

[8] A. J. Onwuegbuzie, et al., "An exemplar for teaching and learning qualitative research," The Qualitative Report, vol. 17 , no. 1, pp. 16-77, 2012. 
[9] L. Flowerdew, "An integration of corpus-based and genre-based approaches to text analysis in EAP/ESP: Countering criticisms against corpus-based methodologies," English for specific purposes, vol. 24, no. 3, pp. 321-332, 2005.

[10] G. Dean, "Grammar for improving writing and reading in secondary school," Routledge, 2014.

[11] D. Gillard, "The Bullock Report: A Language for Life: Improvement in Language Competence," Bullock Report, 1975.

[12] N. Mohamed, "An exploratory study of the interplay between teachers' beliefs, instructional practices \& professional development," The University of Auckland, 2006.

[13] W. S. Wu, "The Integration of Corpus-based Data into Grammar Instruction: Using Advise, Recommend, and Suggest as an Example," $U$ of Chung Hua, Hsinchu, Taiwan, pp. 67-84, 2016. [Online], Available: http://web.chu.edu.tw/ wswu/publications/papers/journals/07.pdf.

[14] C. F. Meyer, "English corpus linguistics: An introduction," Cambridge University Press, 2002.

[15] D. Biber and S. Conrad, "Corpus Linguistics and Grammar Teaching," London, Pearson Longman, 2018.

[16] J. C. Richards, "Communicative language teaching today," Cambridge University Press, 2006.

[17] D. L. Freeman, "Teaching grammar," Teaching English as a second or foreign language, vol. 3, pp. 251-266, 2001.

[18] S. M. Johnson and S. E. Birkeland, "Pursuing a "sense of success": New teachers explain their career decisions," American Educational Research Journal, vol. 40, no. 3, pp. 581-617, 2003.

[19] U. Romer, "Corpus research applications in second language teaching," Annual review of applied linguistics, vol. 31, pp. 205-225, 2011.

[20] C. F. Chang and C. H. Kuo, "A corpus-based approach to online materials development for writing research articles," English for Specific Purposes, vol. 30, no. 3, pp. 222-234, 2011.

[21] B. C. Camiciottoli, "Interactive discourse structuring in L2 guest lectures: Some insights from a comparative corpus-based study," Journal of English for Academic Purposes, vol. 3, no. 1, pp. 39-54, 2004.

[22] C. S. Butler, "Corpus studies and functional linguistic theories," Functions of language, vol. 11, no. 2, pp. 147-186, 2004.

[23] L. G. Salom, et al., "Lexico-grammatical resources of evaluation in research articles," Trabajos en lingüística aplicada. Asociación Española de Lingüística Aplicada, AESLA, 2001.

[24] D. Biber and B. Gray, "Discourse characteristics of writing and speaking task types on the TOEFL ibt ${ }^{\circledR}$ test: a lexico-grammatical analysis," ETS Research Report Series, 2013.

[25] H. Stotesbury, "Evaluation in research article abstracts in the narrative and hard sciences," Journal of English for Academic Purposes, vol. 2, no. 4, pp. 327-341, 2003.

[26] B. E. Gray, "Exploring academic writing through corpus linguistics: When discipline tells only part of the story," Diss. Northern Arizona University, 2011.

[27] M. Holtz, "Lexico-grammatical properties of abstracts and research articles: A corpus-based study of scientific discourse from multiple disciplines,” Ph.D. Thesis, Technische Universitat, 2011. 